\title{
Sea surface height variations in the South China Sea from satellite altimetry
}

\author{
Ping-Tung SHAW a , Shenn-Yu CHAO ${ }^{b}$, Lee-Lueng FU ${ }^{c}$ \\ ${ }^{a}$ Department of Marine, Earth and Atmospheric Sciences, North Carolina State University, P.O. Box 8208, Raleigh, \\ NC 27695, USA \\ ${ }^{b}$ Horn Point Laboratory, University of Maryland Center for Environmental Science, P.O. Box 0775, Cambridge, \\ MA 21613, USA \\ ${ }^{\mathrm{c}}$ Jet Propulsion Laboratory, California Institute of Technology, 4800 Oak Grove Drive, Pasadena, CA 91109, USA
}

(Received 22 October 1997, revised 2 October 1998, accepted 9 October 1998)

\begin{abstract}
Sea surface elevation in the South China Sea is examined in the Topex/Poseidon altimeter data from 1992 to 1995. Sea level anomalies are smoothed along satellite tracks and in time with tidal errors reduced by harmonic analysis. The smoothed data are sampled every ten days with an along-track separation of about $40 \mathrm{~km}$. The data reveal significant annual variations in sea level. In winter, low sea level is over the entire deep basin with two local lows centred off Luzon and the Sunda Shelf. In summer, sea level is high off Luzon and off the Sunda Shelf, and a low off Vietnam separates the two highs. The boundary between the Vietnam low and Sunda high coincides with the location of a jet leaving the coast of Vietnam described in earlier studies. Principal component analysis shows that the sea level variation consists mainly of two modes, corresponding well to the first two modes of the wind stress curl. Mode 1 represents the oscillation in the southern basin and shows little inter-annual variation. The mode 2 oscillation is weak in the southern basin and is strongest off central Vietnam. During the winters of 1992-1993 and 1994-1995 and the following summers, the wind stress curl is weak, and the mode 2 sea level variation in the northern basin is reduced, resulting in weaker winter and summer gyres. Weakening of the Vietnam low in summer implies diminishing of the eastward jet leaving the coast of Vietnam. The results are consistent with model simulations. (C) Elsevier, Paris / Ifremer / Cnrs / Ird
\end{abstract}

\section{South China Sea / sea level / wind stress curl / altimetry / Topex/Poseidon}

Résumé - Variations du niveau de la mer de Chine méridionale observées par altimétrie satellitale. Les variations du niveau de la mer de Chine méridionale sont examinées à partir des données Topex/Poseidon pour la période 1992-1995. Les anomalies de niveau de la mer sont lissées le long des traces des satellites, à la fois dans le temps et dans l'espace, et en réduisant les erreurs dues à la marée par une analyse harmonique. Les données lissées sont échantillonnées tous les $10 \mathrm{j}$ avec une distance entre les traces d'environ $40 \mathrm{~km}$. Les variations annuelles du niveau de la mer sont significatives. En hiver, le niveau est bas dans la région où le bassin est profond, avec deux minima marqués près de Luzon et du plateau de la Sonde. En été, la situation est inverse avec deux maxima au large de Luzon et du plateau de la Sonde séparés par un minimum au large du Vietnam. La limite entre le creux au large du Vietnam et la bosse au large du platcau de la Sonde coöncide avec un jet partant de la côte du Vietnam et déjà décrit antérieurement. Dans la variabilité annuelle, l'analyse en composantes principales des séries temporelles met en évidence deux modes principaux qui peuvent être directement reliés aux deux premiers modes du rotationnel du vent. Le mode 1 représente l'oscillation dans le bassin méridional et montre peu de variabilité interannuelle. Le mode 2 a une amplitude faible dans la partie sud du bassin et forte au large du Vietnam. Pendant les hivers 1992-1993 et 1994-1995 et les étés suivants, le rotationnel du vent est faible et le mode 2 est réduit dans la partie nord du bassin, ce qui affaiblit les circulations hivernales et estivales. L'atténuation du creux au large du Vietnam en été diminue l'intensité du jet dirigé vers l'est à partir de la côte du Vietnam. Les résultats sont en bon accord avec les simulations. $\odot$ Elsevier, Paris / Ifremer / Cnrs / Ird

mer de Chine méridionale / niveau de la mer / rotationnel du vent / altimétrie satellitale / Topex/Poseidon 


\section{INTRODUCTION}

The South China Sea is the largest marginal sea in the tropics, covering an area from the equator to $23^{\circ} \mathrm{N}$ and from $99^{\circ} \mathrm{E}$ to $121^{\circ} \mathrm{E}$ with a maximum depth reaching $5000 \mathrm{~m}$ (figure 1). Its deep central basin is bordered by two hroad shelf regions with depths of less than $100 \mathrm{~m}$. The northern one, including the area south of China and the Gulf of Tonkin, extends from Taiwan southwestward to $13^{\circ} \mathrm{N}$. The southern shelf consists of the Gulf of Thailand to the west and the Sunda Shelf between the Malay Peninsula and Borneo. The Sunda Shelf is connected to the Java Sea to the south (outside the map in figure 1) and the Indian Ocean through the Strait of Malacca. On the east side, the continental slope is steep with practically no continental shelf. The Philippines and Palawan separate the South China Sea from the Pacific Ocean with three deep openings. The widest and deepest is the Luzon Strait. At a sill depth of about $2000 \mathrm{~m}$, it is the major pathway of Pacific waters entering the basin. Two narrower and shallower passages to the north and south of the Palawan Island connect the South China Sea to the Sulu Sea, but their collective volumetric flux is too small to affect the water characteristics in the basin.

Circulation in the basin is driven by the southwest monsoon in summer and the northeast monsoon in winter. The resulting summer anticyclonic gyre and the winter cyclonic gyre as well as the transition hetween them have been documented by Wyrtki [19]. Mesoscale features

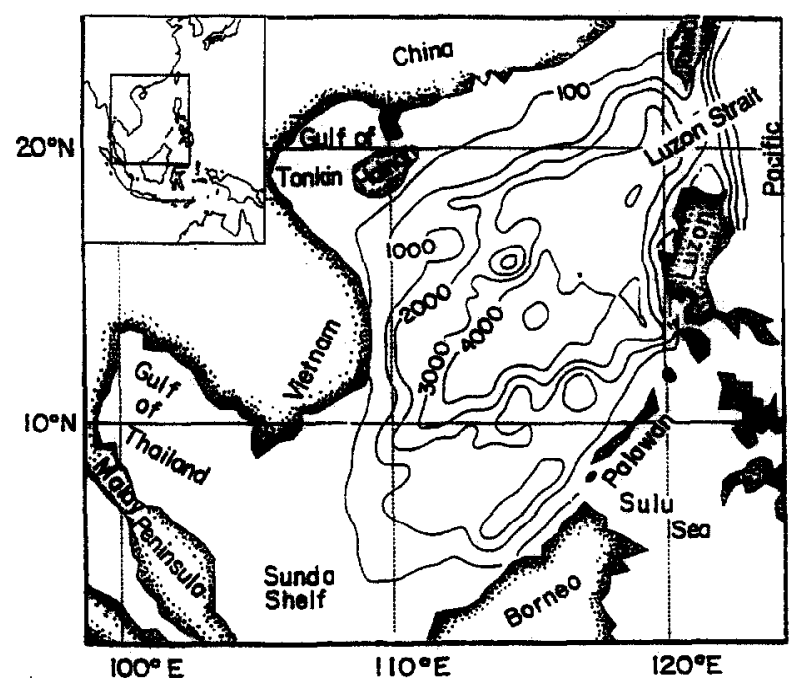

Figure 1. Map of the South China Sea with the 100, 1000, 2000, 3000 and $4000 \mathrm{~m}$ isobaths shown. The inset gives the geographical location of the basin. associated with the two seasonal circulation patterns include the reversal of a western boundary current off Vietnam, the appearance of a warm current south of China in winter [2], and upwelling off Vietnam in summer [19] and off Luzon in winter [15]. Recent numerical simulations have provided much insight to the annual and inter-annual variations of circulation and mesoscale features. Using a three-dimensional primitive-equation model driven by the climatological monthly wind field, Shaw and Chao [14] reproduced circulation patterns suggested by the climatology atlases of Wyrtki [19]: a cyclonic gyre in winter and an anticyclonic gyre in summer, both intensifying along the western boundary of the basin (figure 2). Driven by the northeast monsoon, the southward jet in winter follows the western boundary throughout. Under the southwest monsoon, however, the northward jet in summer moves away from the coast of Vietnam at $12^{\circ} \mathrm{N}$. The sea level field in support of the surface circulation in summer is high on the southeast side and low on the west side. In winter, sea level is high on the west and south sides, and low on the northeast side. The pressure gradient south of China provides a driving force for the South China Sea Warm Current in winter [2]. Other simulations identified upwelling processes both in deep and shallow waters [3]. The simulated circulation patterns generally agree with the earlier observations in the South China Sea. Extending the model from seasonal to inter-annual time scales, Chao et al. [4] further established the relationship between the heat content of the upper ocean and upwelling. During the 19821983 El Niño when the monsoon winds were weak, the circulation of the South China Sea was weak, and a reduced upwelling rate lead to warming of the upper ocean in the basin.

The disparity between the summer anticyclonic gyre and the winter cyclonic gyre warrants discussion. Figure 3 shows the monthly wind stress curl average for the period 1982-1995 for August and December. In August, the wind stress curl is negative in the south and positive in the north, with the zero line running from southwest to northeast. This pattern is essentially reversed in December with the line of zero curls being farther north. Linear circulation theory [17] would suggest the formation of two gyres separated by the line of zero wind stress curl in the central basin in both summer and winter. Both gyres should intensify along the western boundary of the basin as a result of the Earth's $\beta$-effect. In summer, the southern gyre is expected to be anticyclonic and confined to the south, while a cyclonic gyre occupies most of the northern 

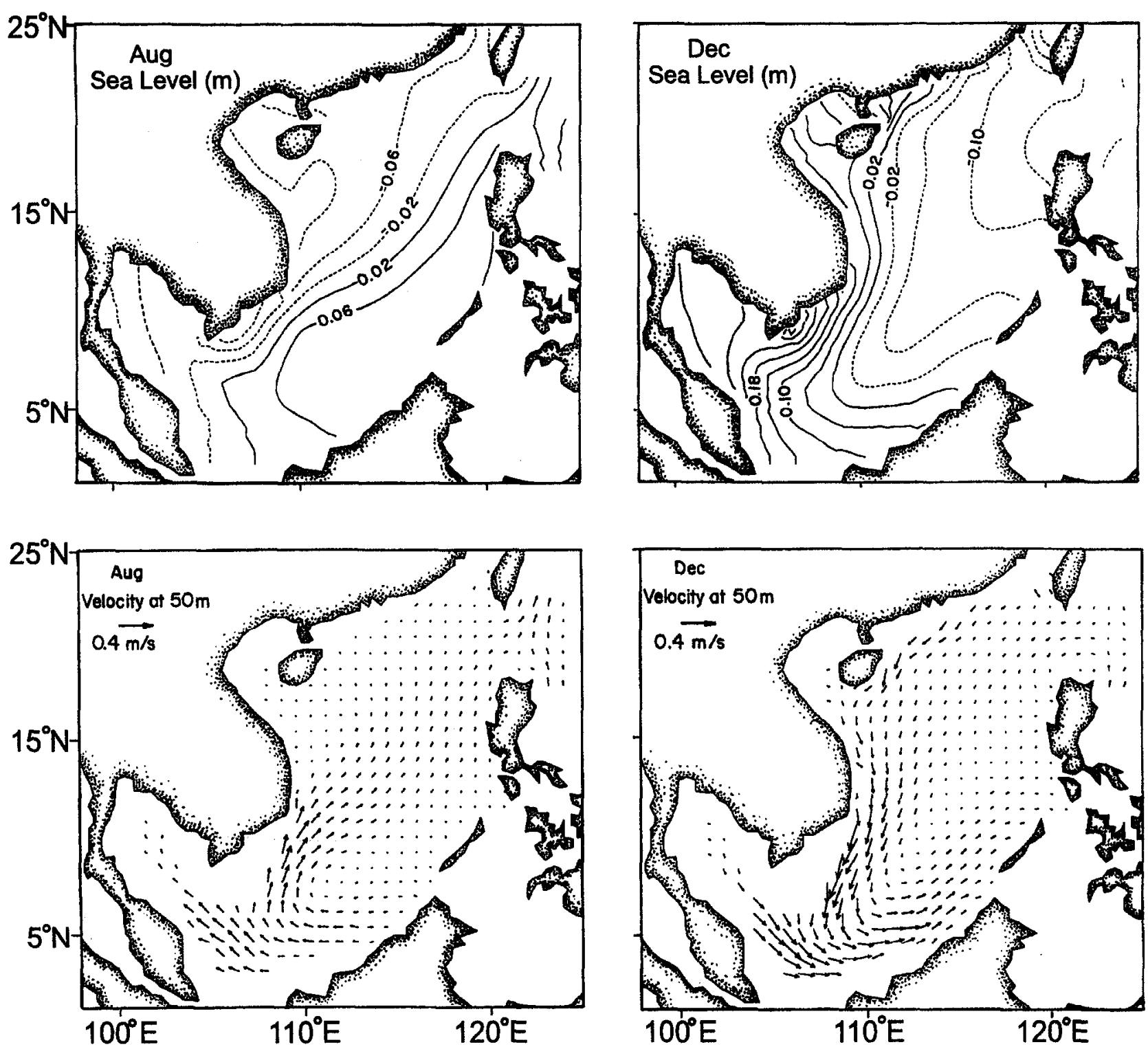

Figure 2. The climatological sea level field (upper panels) and horizontal velocity at $50 \mathrm{~m}$ (lower panels) in August and December from the simulation of Shaw and Chao [14]. The contour interval for sea level is $0.04 \mathrm{~m}$ with negative contours in dashed lines. The scale for velocity vectors is $0.4 \mathrm{~m} \mathrm{~s}^{-1}$.

basin. In winter, the area of positive wind stress curls in the south extends farther north, indicating mostly cyclonic circulation in the basin; the northern gyre is expected to be confined near the continental margin. Because the northeasterly monsoon has fully developed over the entire basin in December, the downwind coastal jet over the continental slope on the north and west sides of the basin could overwhelm the would-be anticyclonic gyre driven by the wind stress curl. This scenario may explain the two-gyre system and its disparity in summer and winter, indicating the importance of wind stress curls in driving the circulation in the deep basin.

The foregoing climatological description provides the basis to launch the present investigation. In previous studies, sea level fields derived from distributed tide gauge stations or numerical models remain to be verified. Further, considerable deviations from climatology occurred in the early 1990s. With the Southern Oscillation index remaining negative, the 1990-1995 period has been 

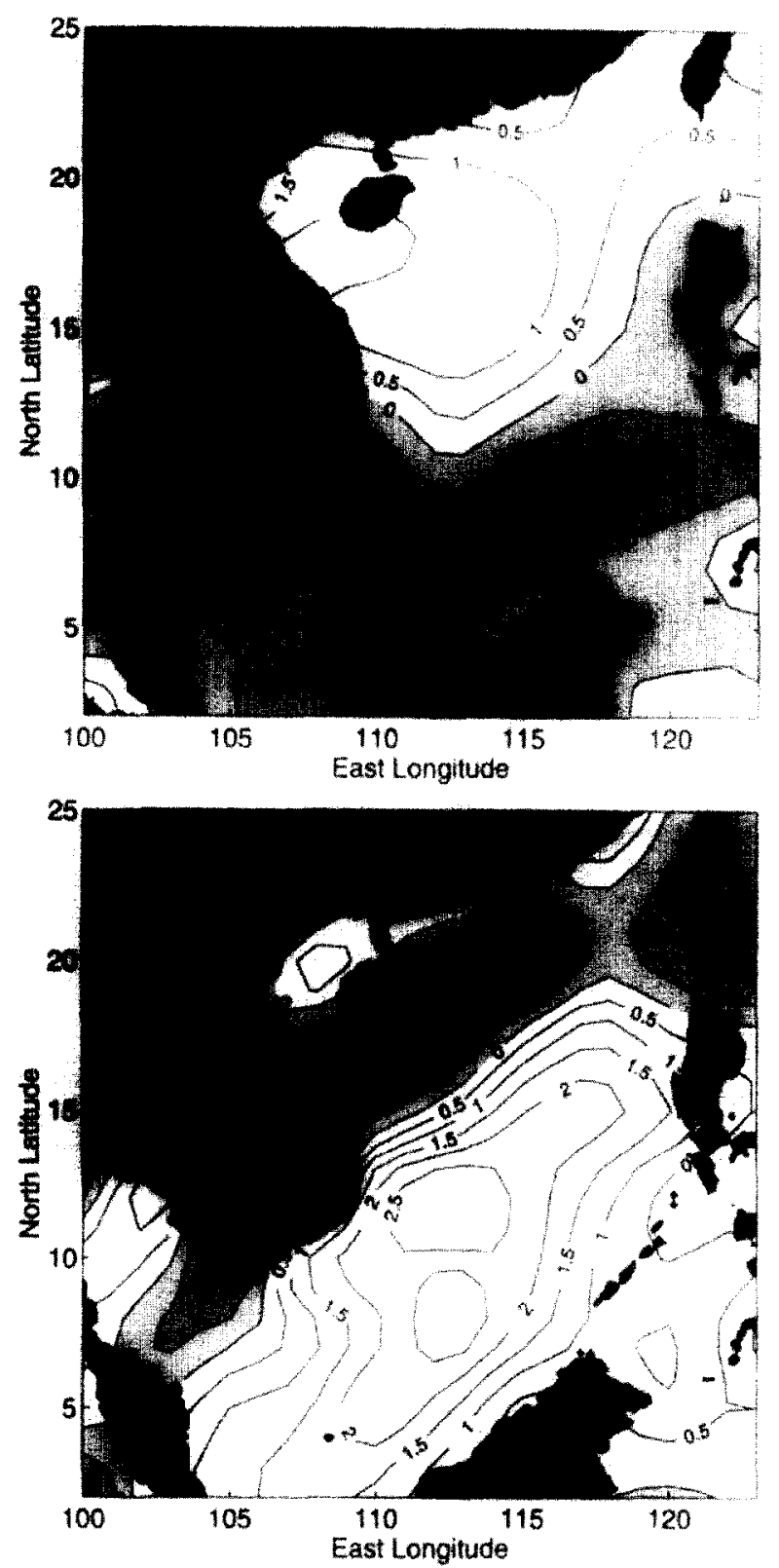

Figure 3. The climatological wind stress curl in August and December, averaged from the monthly data of Kalnay et al. [9] between 1982 and 1995. Contour intervals are $0.5 \times 10^{-7} \mathrm{~N} \mathrm{~m}^{-3}$ with regions of negative curls shaded.

hailed as the longest El Niño on record [18]. Chao et al. [4] have shown that the South China Sea circulation is generally weaker than normal during El Niño when the monsoon winds arc reduced. Recent satellite altimeter data from Topex/Poseidon have given unprecedented spatial and temporal coverage of sea level variations in the
South China Sea. The altimeter data from fall 1992 to early summer 1995 are analysed below to provide an independent verification of climatological descriptions based on hydrography and numerical models, and to better clarify the relationship between the circulation patterns and the wind stress curl. Although the data are too short-term to give a comprehensive description of the inter-annual variations in the South China Sea, some year-to-year variations are noted in the data and are consistent with those inferred from model simulation.

Between 1992 and 1995, three episodes of warming in the sea surface temperature anomaly field in the Equatorial Pacific have been identified [7]: warming in 19911992, nearly normal conditions in mid-1992, a second warming in early 1993, normal conditions again from late 1993 to mid-1994, and a third warm event beginning in late 1994. The winter monsoon in the South China Sea is known to weaken during warm events in the Equatorial Pacific [20]. Thus, circulation in the South China Sea is expected to be in weakened conditions except in winter 1993-1994 and summer 1994. Winter 1992-1993 is at the beginning of a warm event; circulation is probably not much weakened as in the winter of 1994-1995.

The paper is organized as follows. After describing the altimeter data and the analysis methods, we first show several snapshots of the sea level field to characterize the seasonal patterns and their variations in different years. Seasonal and inter-annual variations of sea level and the wind stress curl are then described in terms of empirical orthogonal modes. The similarities in modal structures of the altimeter sea level and the wind stress curl are discussed to suggest the driving mechanism of the South China Sea circulation.

\section{MATERIALS AND METHODS}

Sea level anomalies from Topex/Poseidon in the region from $100^{\circ} \mathrm{E}$ to $130^{\circ} \mathrm{E}$ and from $0^{\circ} \mathrm{N}$ to $30^{\circ} \mathrm{N}$ are obtained from the Jet Propulsion Laboratory (JPL). Initial data processing performed at JPL includes the standard correction for the atmospheric effects and the removal of a mean sea surface and the tides [1]. The data used in this study cover the period from September 23, 1992 to June 21,1995 , corresponding to the 10 -day cycles $1-101$. The location of the ground tracks in the vicinity of the South China Sea is shown in figure 4. The along-track spatial resolution is about $6 \mathrm{~km}$. After processing, as described below, time series of sea level anomalies with a common 


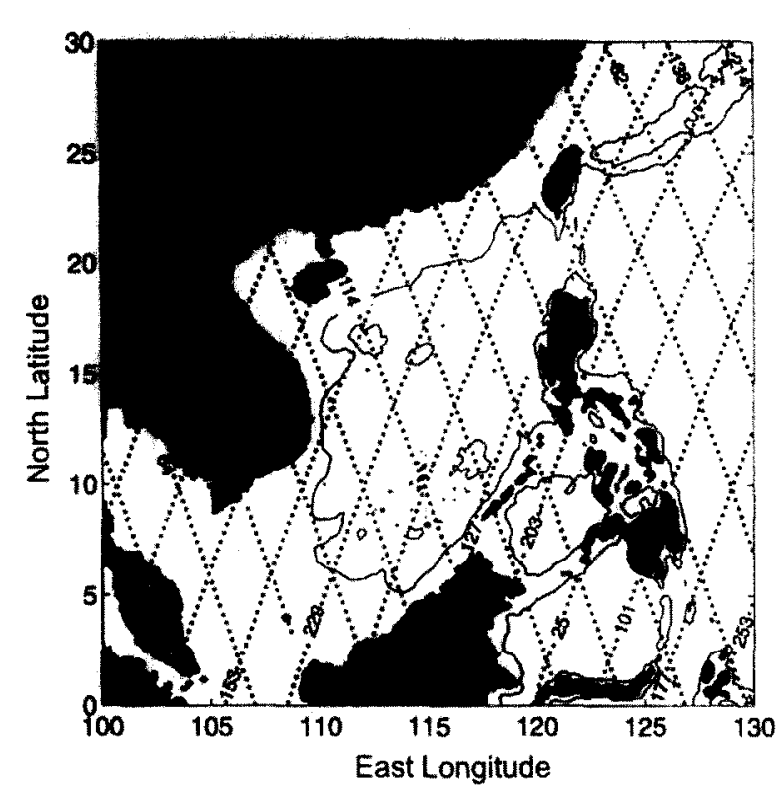

Figure 4. Satellite tracks in the South China Sea with the $1000 \mathrm{~m}$ isobath shown.

time basis are obtained. They are sampled every ten days with an along-track separation of $40 \mathrm{~km}$.

The satellite has a repetitive orbit with a 10-day period, which gives a Nyquist period of about 20 days. At this sampling rate, the first six tidal components, $\mathrm{M}_{2}, \mathrm{~S}_{2}, \mathrm{~N}_{2}$, $\mathrm{K}_{\mathrm{f}}, \mathrm{O}_{1}$, and $\mathrm{P}_{1}$, alias to $62.11,58.74,49.53,173.19,45.11$ and 88.89 days, respectively [16]. In the South China Sea, semidiurnal tides propagate from the Luzon Strait to the Gulf of Thailand through amphidromic systems, while strong diurnal tides are present in the Gulf of Tonkin and Gulf of Thailand [11]. Thus, tidal aliasing contributes erroneous oscillations at periods $1.5-2,3$ and 6 months. Although tidal correction has been applied to the data based on a deep-water tide model developed at the University of Texas [10], the result is not satisfactory. Possible tidal aliases are illustrated in the spectrum of sca level anomalies at three locations in figure 5. In the Gulf of Thailand (figure 5a), large peaks at 60 days and 180 days are present, and a smaller peak is at 90 days. On the shelf east of Hainan (figure 5b), the 60-day and 180day peaks are lower but still significant. In the deep water (figure 5c), all three peaks are evident.

Since this study concerns seasonal and inter-annual variations, aliasing at periods between 1.5 and 2 months can be eliminated by smoothing, but smoothing cannot eliminate the 3-month and 6-month aliases from diurnal tides.
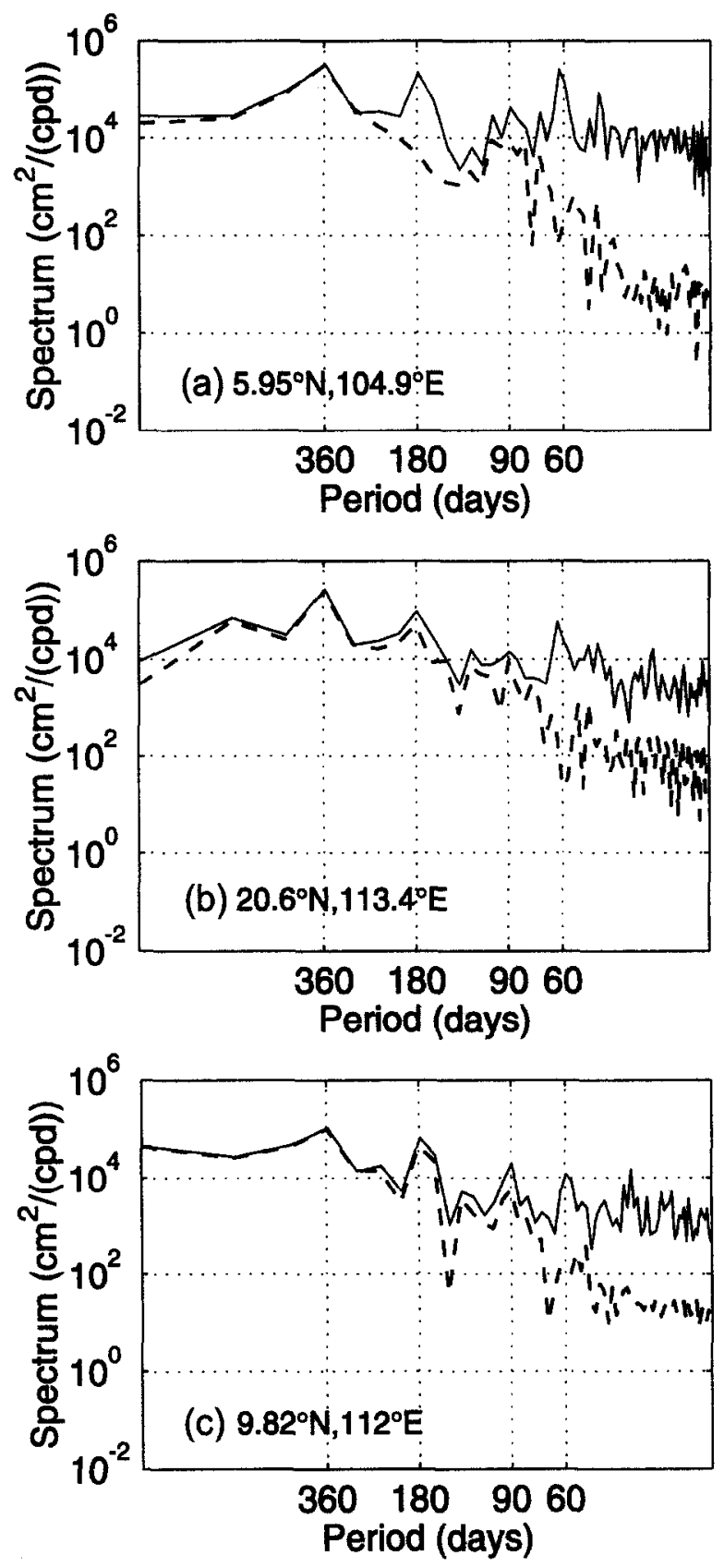

Figure 5. Spectra of sea level calculated from raw data (solid curves) and smoothed data (dashed curves) at selected locations: (a) in the Gulf of Thailand, (b) on the continental shelf east of Hainan, and (c) in the central basin. Periods at $360,180,90$ and 60 days are marked.

Therefore, harmonic analysis of the six tidal components mentioned above is performed on the raw data of 101 cycles. After tides are subtracted, data are spatially smoothed along satellite tracks and sampled every $40 \mathrm{~km}$. 
The weighting function for spatial smoothing is expl-2(x/ $\left.L)^{2}\right]$, where $x$ is distance along a track and $L=1^{\circ}$. The data are then smoothed in time using a weighting function, $\exp \left[-2(t / T)^{2}\right]$, where $t$ is time and $T=30$ days. The final data are sampled cvery ten days. Spectra of the processed data are overlaid in figure 5. In the Gulf of Thailand, both the 2-month and 6-month peaks are completely eliminated, indicating that the semi-annual peak in the Gulf is due to aliasing from diurnal tides. Energy at 90 days is also reduced. On the shelf east of Hainan and in the deep water (figures $5 \mathrm{~b}, \mathrm{c}$ ), the 60-day peak is eliminated, while the semi-annual peak and the 90-day peak are not affected by harmonic analysis. Figure 5 shows that harmonic analysis discriminates tidal aliasing from signals fairly well. Comparing the smoothed time series with the raw data at the three locations (figure 6) indicates that high frequency oscillations and aliases are effectively reduced, while the seasonal trend is preserved.

After processing, sea level anomalies are examined in terms of empirical orthogonal functions (EOF), using principal component analysis [12]. Since standing oscillations associated with the rise and fall of sea level in summer and winter dominate in the central basin, real instead of complex principal components are used. Let $Z$ be a matrix consisting of time series of sea level anomalies in column vectors. Its size is $n$ by $m$, where $n$ is the length of each time series and $m$ is the total number of time series. The principal components are obtained by finding the eigenvectors of the matrix $\mathrm{S}=\mathrm{Z} \mathrm{Z}^{\prime} /(m-1)$, where prime represents complex conjugate transpose. Let $\Lambda$ be a matrix with off-diagonal elements being zero and diagonal elements being eigenvalues of $S$. The eigenvalue problem is $\mathrm{Se}=\mathrm{e} \Lambda$. Expansion of time series in terms of the principal components gives $Z=c A$, where $A=e^{\prime} Z$. Note that we have formulated the EOF decomposition in terms of an $n \times n$ covariance matrix $\mathrm{S}$, whose elements are calculated by averaging over space. Therefore, each column of $e$, which represents the eigenvector of one mode, describes the temporal variation of that mode. Spatial dependence is given by the corresponding rows in the $n \times m$ matrix A. The amplitude of A depends on normalization of e. In this paper, each eigenvector in $\mathbf{e}$ is normalized to unit length and is nondimensional.

Earlier models have shown that monsoon winds are the main driving force of the basin circulation. Chao et al. [4] further suggest the importance of the wind stress curl in driving the circulation gyres. Therefore, principal components of the wind stress curl hetween 1992 and 1995 are calculated using monthly wind data trom the NCEP/ NCAR Reanalysis Project [9].

\section{RESULTS}

\subsection{Sea level patterns}

Figure 7 shows several snapshots of the sea level field during the three-year period. Panels (a)-(e) cover a oneyear period from the beginning of the northeast monsoon in October 1992 to a fully developed southwest monsoon in August 1993. Panels (f)-(h) illustrate deviations from the summer and winter patterns of 1992-1993. Despite some year-to-year variations, main features in the seasonal variation of sea level are captured in the sequence of plots from (a) to (e). In October 1992 (figure 7a), high sea level is along the coast of China but has not yet reached the Gulf of Thailand. Of more interest than the sea level rise on the shelf is a region of low sea level extending from Vietnam northeastward to the coast of Luzon in the central basin; a cyclonic gyre is gradually taking shape. Also, noticeable is a weak low at the edge of the Sunda Shelf south of this low. In the following months, high sea level reaches the Gulf of Thailand and Sunda Shelf as shown in the sea level distribution on December 2, 1992 (figure 7b). Both lows in the central basin and on the Sunda Shelf intensify. The Sunda low remains at the same location while expanding, but the Vietnam low to the north extends northeastward toward Luzon. The two lows nearly cover the entire deep basin to form a fully developed winter sea level field.

The winter pattern persists well into January and decays afterwards. On April 11, 1993, only a weak low, remnants of the central gyre, remains to the west of Luzon, while a high appears east of Vietnam (figure 7c). Otherwise, the sea level field is featureless. Into summer, low sea level extends northeastward along the coast from the Gulf of Thailand to the Taiwan Strait (figure 7d). The high off Vietnam persists, and a stronger high develops northeast of it. The summer sea level pattern fully develops in August 1993 (figure 7e). A weak high replaces the winter low off Sunda Shelf. A band of low sea level separates the Sunda high from the high sea level in the northern basin.

Both the winter and summer gyres in the following year are stronger. In December 1993, low sea level extends from the Sunda Shelf to the Luzon Strait (figure 7f), suggesting a basin-wide cyclonic gyre as shown in the 

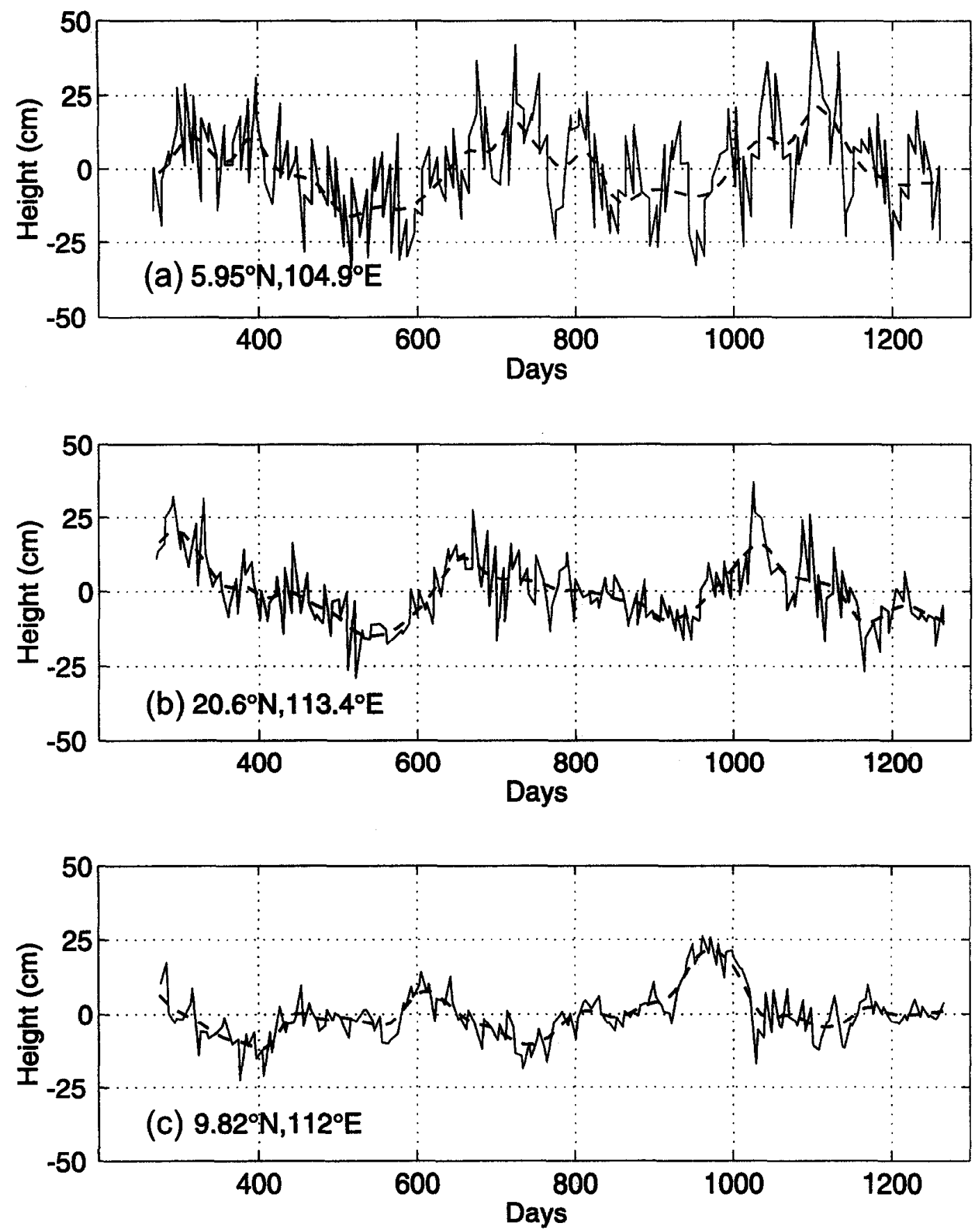

Figure 6. Time series of raw (solid curves) and smoothed (dashed curves) sea level at the locations shown in figure 5. Days are from January $1,1992$.

model. In the summer of 1994 (figure $7 \mathrm{~g}$ ), high sea level in the northern basin is farther north in the Luzon Strait; low sea level is over most of the northwestern basin. The low off Vietnam and the Sunda high form a dipole with a strong north-south sea level gradient at $12^{\circ} \mathrm{N}$. The sea level field becomes extremely weak in the following winter. In December 1994, the Sunda low nearly disappears; only a Luzon low is present (figure $7 \mathrm{~h}$ ). 

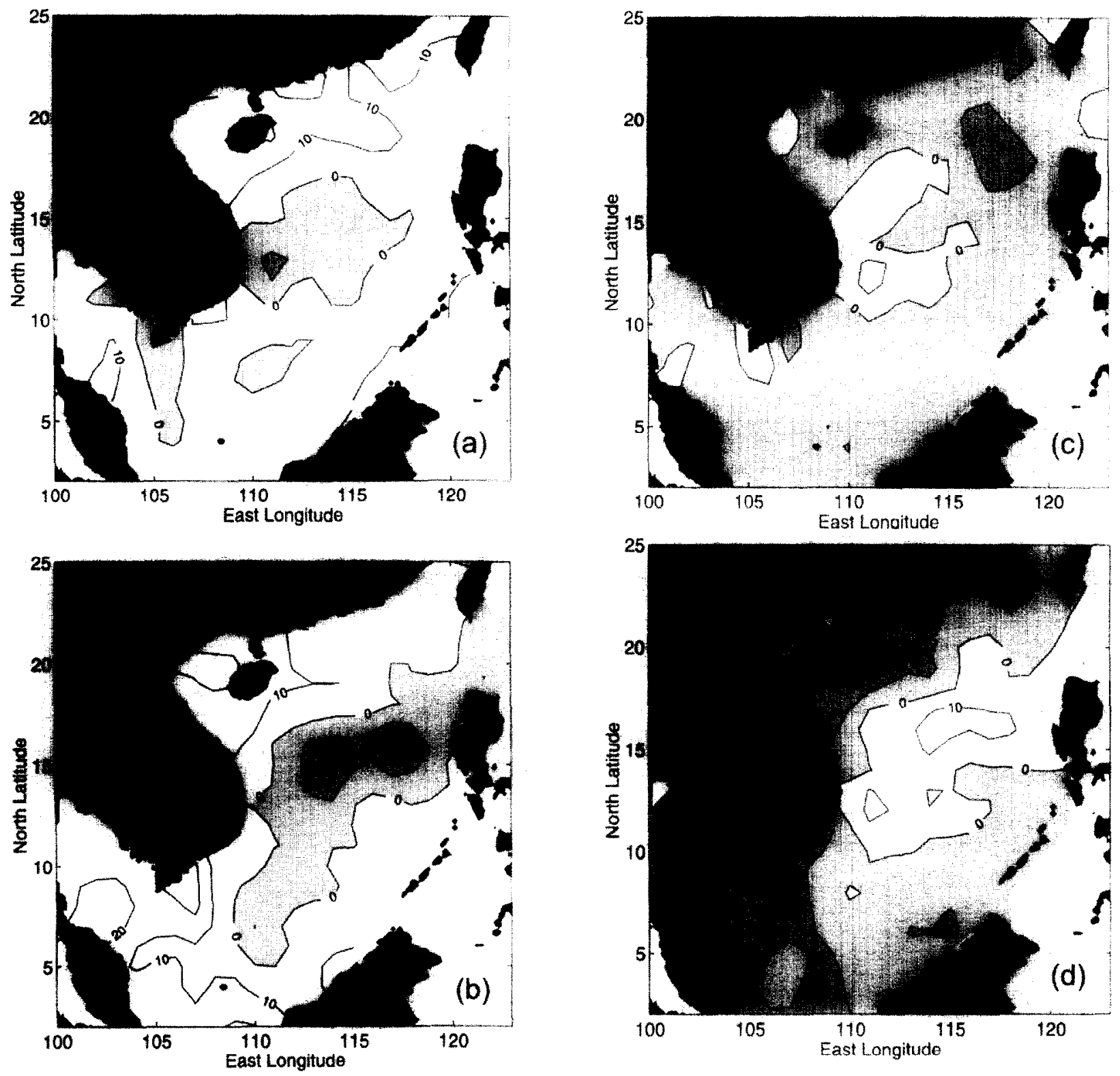

Figure 7. Smoothed sea level fields on (a) Octoher 13, 1992, (b) December 2, 1992, (c) April 11, 1992. (d) June 10, 1993, (e) August 9, 1993, (f) December 27, 1993, (g) August 24, 1994, and (h) December 12, 1994. Contour intervals are $10 \mathrm{~cm}$ and regions of negative sea level anomalies are shaded.

On the continental shelf, the sea level field depicted in the altimeter data shows many similarities to model simulations and historical observations. Sea level in the altimeter data is highest south of China in October. Tide gauge measurements [8] and numerical model simulations [4] consistently show that sea level in the northern reaches of the South China Sea is highest in October. The Septemher-Octoher emergence of the northeast monsoon at northern latitudes and its expansion equatorward at the expense of a diminishing southwest monsoon pile up waters there. In the Gulf of Tonkin and Gulf of Thailand, high sea level in winter and low sea level in summer are depicted in figure 2 as well as in Wyrtki's atlases [19]. In the deeper part of the basin, sea level variations in figure 7 are consistent with the climatological circulation described in model simulations and historical observa- 

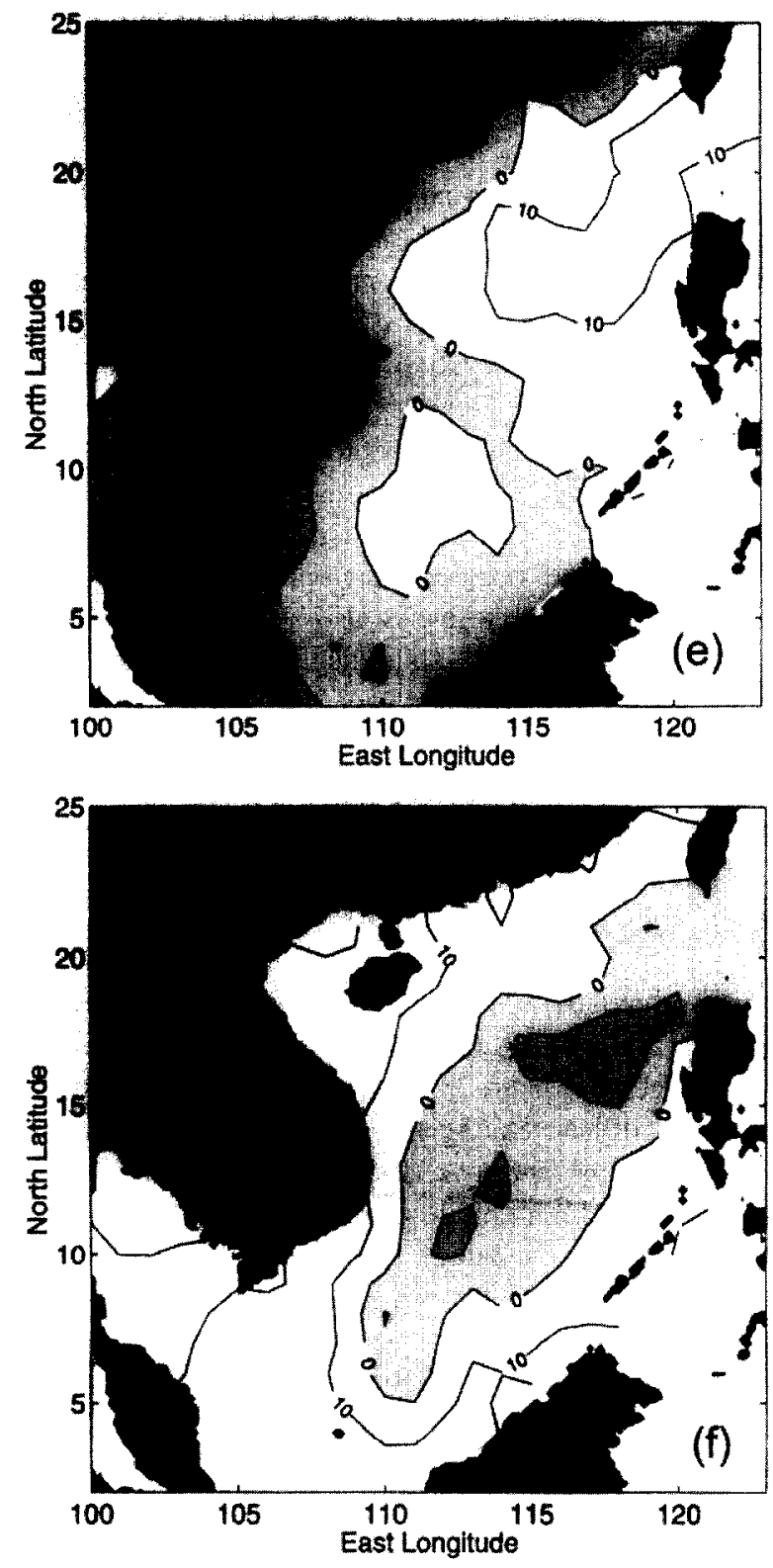

Figure 7. (contd.)

tions as well. In the climatological data (figure 2), low sea level is associated with the cyclonic winter gyre in the central basin, and high sea level with the anticyclonic summer gyre. The low in winter extends over the entire basin, while the high in summer is limited to the southern basin. A low associated with a smaller cyclonic gyre off Sunda Shelf could also be seen in the monthly simulations [4: figure 14]. An eastward jet marks the northern boundary of the anticyclonic summer gyre. The sea level patterns in winter 1993-1994 and in summer 1994 fit the
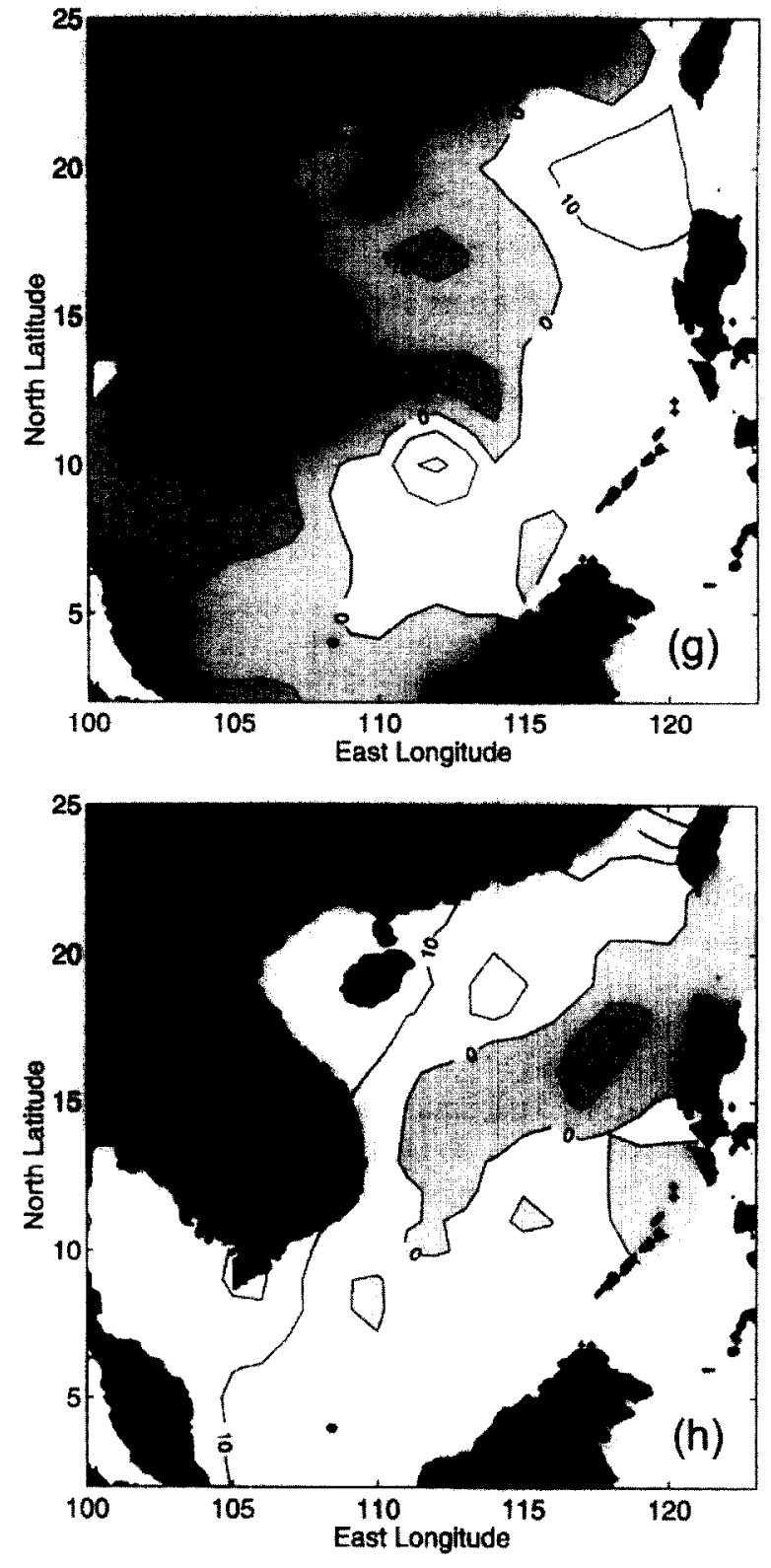

classical description well (figures 7f, g). In winter, the Luzon low and Sunda low strengthen and merge, forming the classical basin-wide gyre. In summer, the Luzon high is confined in the vicinity of the Luzon Strait. The Vietnam low and Sunda high form a dipole. The sea level gradients thus formed imply an eastward jet leaving the coast of Vietnam.

In contrast to the sea level patterns in winter 1993-1994 and in summer 1994, sea level fields in summer 1993 (figure 7e) and in winter 1994-1995 (figure 7h) are much 
weaker, while the winter of 1992-1993 is slightly weaker (figure $7 \mathrm{~b}$ ). In the time span of our data, the period from late 1993 to mid-1994 is probably the only sizable interval when the normal climatological condition prevails in the South China Sca.

\subsection{Temporal variations of sea level}

Temporal variations in sea level are shown in the spacetime plots along satellite tracks. Variations of sea level off Vietnam are plotted along track 38 from $5^{\circ} \mathrm{N}, 114^{\circ} \mathrm{E}$ to the Gulf of Tonkin in figure $8 \mathrm{a}$ (see figure 4 for track location). Oscillations north of $15^{\circ} \mathrm{N}$ demonstrate the annual rise and fall of sea level in the Gulf of Tonkin. South of this latitude, track 38 is in deeper water. Between $9^{\circ} \mathrm{N}$ and $14^{\circ} \mathrm{N}$, the highs and lows are associated with sea level variations in the winter and summer gyres. In August, sea level anomalies are negative north of $11^{\circ} \mathrm{N}$ with a minimum near $13^{\circ} \mathrm{N}$ and positive between $9^{\circ} \mathrm{N}$ and $11^{\circ} \mathrm{N}$. The positive and negative anomalies represent the dipole off Vietnam in summer (figure $7 \mathrm{~g}$ ). Persistence of negative anomalies between $11^{\circ} \mathrm{N}$ and $14^{\circ} \mathrm{N}$ into December demonstrates the formation of the northern gyre after October. The anomaly between $11^{\circ} \mathrm{N}$ and $14^{\circ} \mathrm{N}$ becomes positive after December, and reaches a maximum in April. The variation corresponds well with weakening of the winter gyre and the formation of a high off Vietnam in April (figure $7 \mathrm{c}$ ). Between $9^{\circ} \mathrm{N}$ and $11^{\circ} \mathrm{N}$, positive anomalies in August become negative after October, following the formation of a low off Sunda Shelf. Anomalies remain negative to the south through May, indicating the persistence of the Sunda low into spring.

Year-to-year variations in sea level anomalies exist along track 38 (figure $8 \mathrm{a}$ ). First, the dipole between $9^{\circ} \mathrm{N}$ and $14^{\circ} \mathrm{N}$ is stronger in August 1994 than in August 1993, consistent with figure 7. Large gradients at $12^{\circ} \mathrm{N}$ in August 1994 suggest the existence of an eastward jet off Vietnam. Second, negative anomalies at $10^{\circ} \mathrm{N}$ are much weaker and of shorter duration in the winter of 1994 1995 than in other two winters. Anomalies are negative from November 1994 through February 1995, while negative anomalies at $10^{\circ} \mathrm{N}$ persist for about 6 months in other two winters. In the winter of 1993-1994, the anomalies not only are the largest but also extend to a latitude farther north than in the other two winters. Large anomalies in late 1993 and small anomalies in late 1995 are demonstrated in figure 7 . Finally, a high, shown as posi- tive sea level anomalies at $13^{\circ} \mathrm{N}$, is strong in spring 1993 and spring 1995, but missing in April 1994.

Sea level variations across the northern gyre are shown along track 12 west of Luzon (figure 8b). This track crosses the northeastern part of the northern gyre. North of $20^{\circ} \mathrm{N}$, the anomalies show high sea level in the fall and low sea level in the spring on the shelf south of China, as expected from figure 7 . In the deep water, alternating positive and negalive anomalies are profound at $17^{\circ} \mathrm{N}$, negative from November to April and positive for the rest of the year. This variation corresponds to a winter low and a summer high off Luzon in the northern basin. Some year-to-year variations exist. During the winter of 1993-1994, large negative anomalies imply a strong Luzon low. The Sunda low is also strong (figure 8a). In the winter of 1994-1995, small negative anomalies imply a weak winter gyre. The sea level field in the early winter of 1992-1993 seems to be weakened slightly, but negative anomalies covering a large latitude range persist into spring 1993.

\subsection{Sea level modes}

The first three modes of sea level variation contain $65 \%$, $13 \%$ and $3 \%$ of the total variance, respectively. Modes 1 and 2 together explain $78 \%$ of the variance and will be discussed further. The spatial dependence of these two modes given by matrix $\mathrm{A}$ is shown in figure 9. Oscillations associated with mode 1 are in phase over the entire deep basin from the Sunda Shelf to Luzon and Taiwan. Large amplitude oscillations in shallow waters on the west side of the basin are out of phase with the deep water oscillations. Oscillations in shallow waters are caused by set-up and set-down of the water level in a closed basin by wind stress [5], while those in the deep water are associated with the winter and summer gyres. The mode 1 contribution to the winter gyre is best represented in the December sea level shown in figure $7 \mathrm{f}$. The local southern and northern extremes off the Sunda Shelf and off Luzon are clearly shown. Mode 2 mainly contributes to oscillations off Vietnam and in the Luzon Strait; oscillations in these two areas are $180^{\circ}$ out of phase. The mode 2 sca level variation in the southern basin is weak. A manifestation of the mode 2 structure is in the April sea level (figure 7c).

Temporal variations of modes 1 and 2 described by eigenvectors in matrix e are shown in figure 10. Mode 1 displays clear annual oscillations with extreme positive and negative values in August and December of each year. 
Track 38

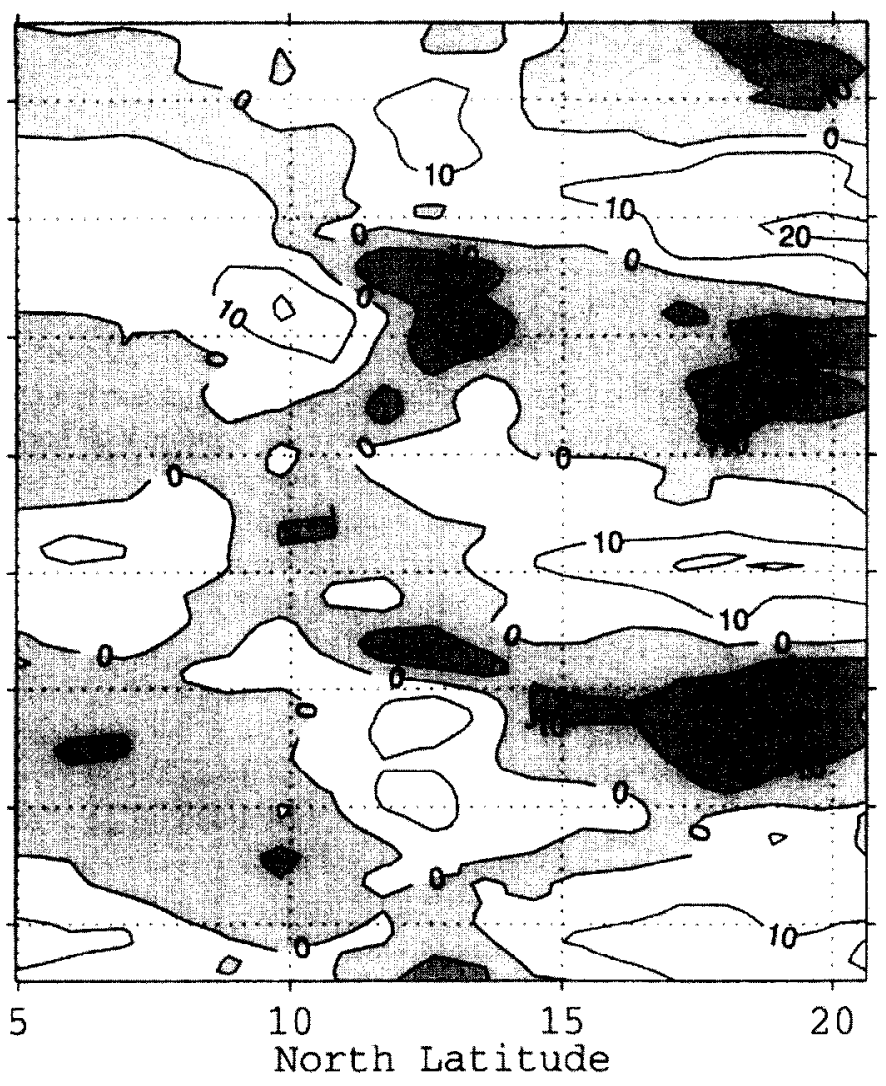

(a)

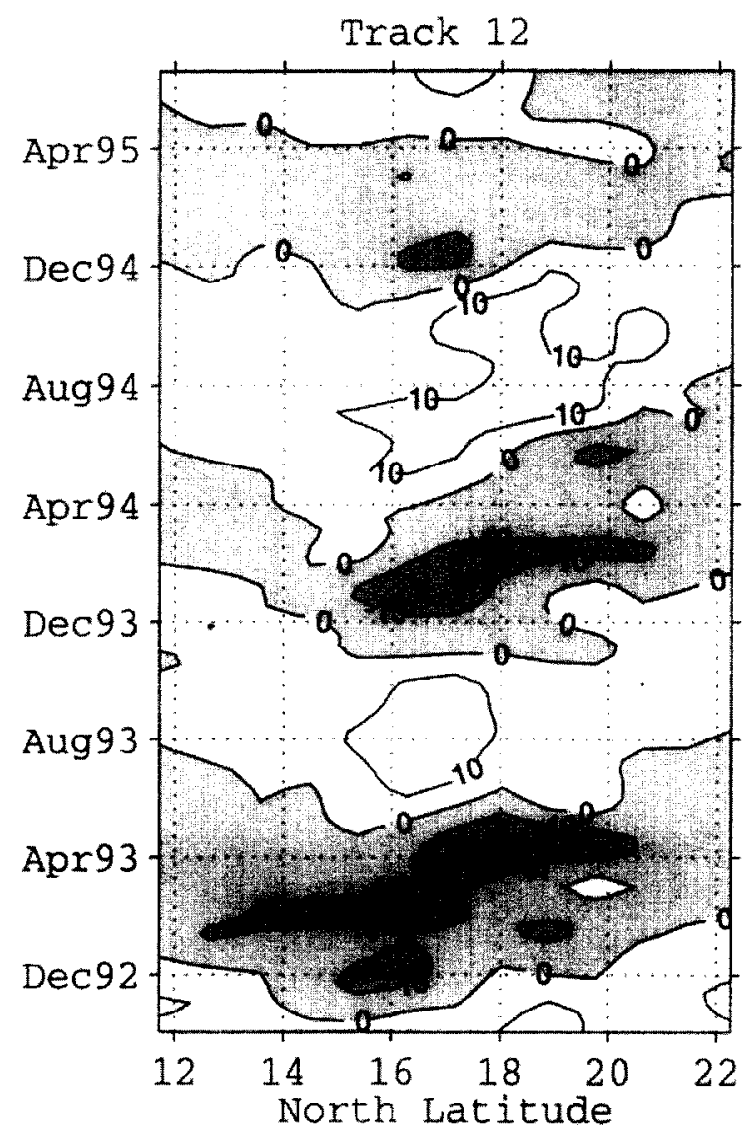

(b)

Figure 8. Temporal and spatial variations of sea level in $\mathrm{cm}$ along tracks (a) 38 and (b) 12. Time marks are at the first day of a month. Contour intervals are $10 \mathrm{~cm}$ and regions of negative sea level anomalies are shaded.

Combining with figure 9 , mode 1 provides large negative sea level anomalies around August 1 and large positive anomalies around December 1 on the western shelves, indicating the set-down and set-up of sea level by monsoon winds. Off Luzon and Sunda Shelf in the deep basin, mode 1 sea level is lowest in December and highest in August, representing the rise and fall of sea level in summer and winter, respectively. Mode 2 also has an annual period, but the extreme positive and negative values are in April and October, respectively. In MarchApril, the mode 1 coefficient is small, and mode 2 dominates the sea level field. From figure $9 \mathrm{~b}$, mode 2 contributes negative anomalies to the remnant winter gyre in the northern basin and positive anomalies off Vietnam in spring (figure $7 \mathrm{c}$ ). In fall, mode 2 contributes to the fall of sea level off Vietnam and the rise of sea level in the northern basin under the developing northeast monsoon (figure 7a).
Mode 1 alone would produce the basin-wide winter and summer gyres; both occupy the entire deep basin. The presence of mode 2 variation contributes to their disparity. In late 1993, a negative mode 2 coefficient persists through December, contributing negative anomalies off Vietnam. The contribution is of the same sign as the Sunda low and enhances the low sea level in the winter gyre (figure 7f). During December in 1992 and 1994, the coefficient of mode 2 changes rapidly from negative to positive (figure 10). A positive mode 2 coefficient contributes positive anomalies off the coast of central Vietnam and weakens the winter gyre (figures $7 \mathrm{~b}, \mathrm{~h}$ ). In August, a negative coefficient of mode 2 contributes negative anomalies off Vietnam when mode 1 contributes positive anomalies to the southern basin. A large contribution from mode 2 would produce a strong dipole, consisting of the Sunda high and a Vietnam low. This is the case in August 1994, when the coefficient of mode 2 is 

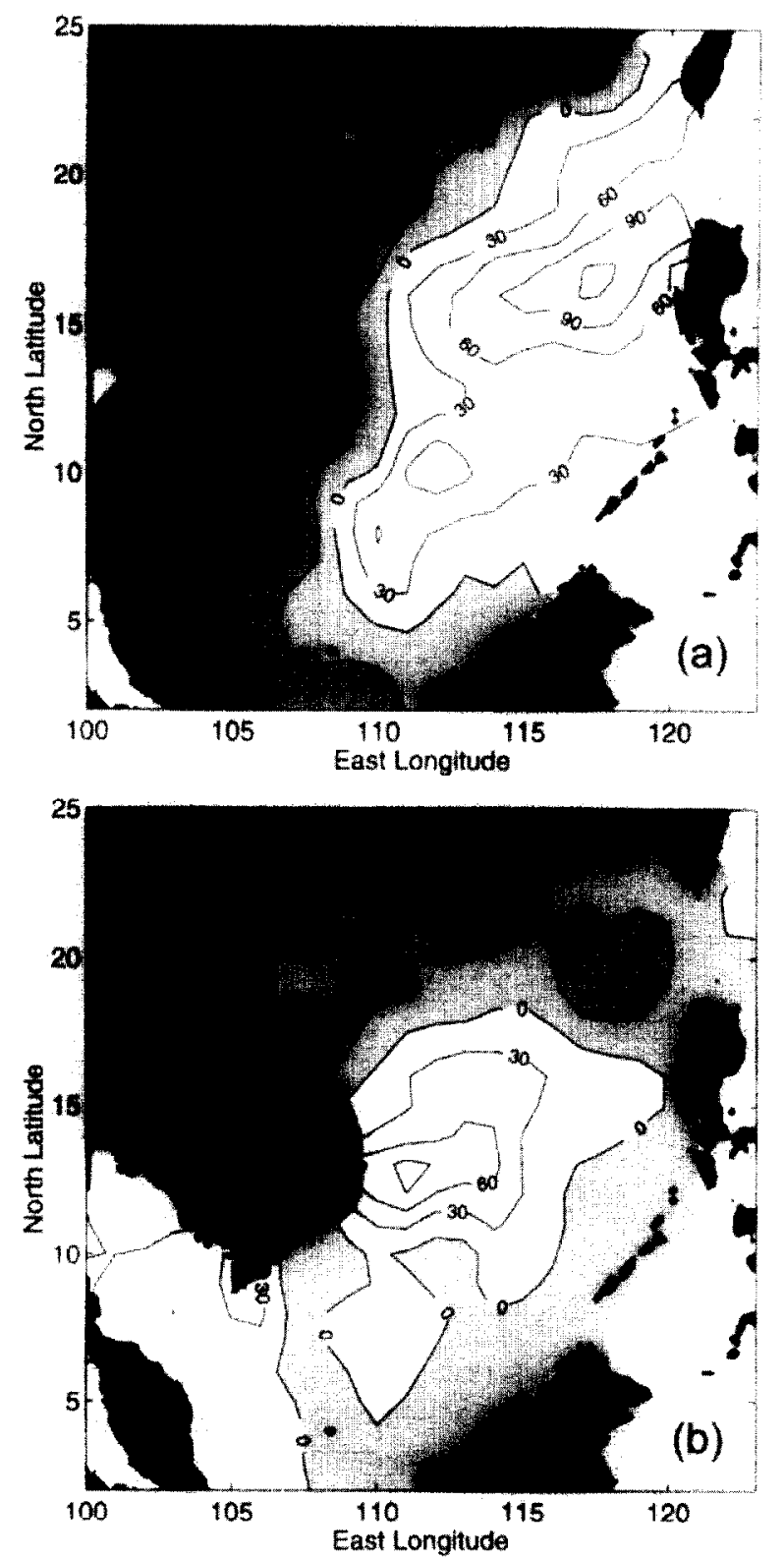

Figure 9. Spatial structure of the first two sea level modes. Contour intervals are $30 \mathrm{~cm}$, and negative contours are shaded.

twice that in August 1993. An eastward jet separating from the coast at $12^{\circ} \mathrm{N}$ would appear. The dipole in sea level is clearly shown in figure $7 \mathrm{~g}$. Thus, mode 2 contribution strengthens the basin gyre in the winter of 1993 1994 and produces a dipole circulation off Vietnam in summer 1994. The mode 2 contribution weakens the basin gyre in the winter of 1994-1995, while lacking the mode 2 contribution prevents the formation of a dipole off central Vietnam in summer 1993.

\subsection{Modes of the wind stress curl}

The first three modes of the wind stress curl explain $51 \%, 23 \%$ and $13 \%$ of the total variance, respectively (figures 11, 12). Mode 1 essentially consists of positive values in the south and negative values in the north. Large negative values are confined near the continental margin south of China. Contribution of the mode 1 wind stress curl to the deep basin is mainly south of $13^{\circ} \mathrm{N}$ in the southern basin. The second mode contributes to the variance in the northern basin between $10^{\circ} \mathrm{N}$ and $18^{\circ} \mathrm{N}$, strongest off central Vietnam. The mode 2 pattern is similar to the spatial structure of mode 2 sea level variation. The coefficients of the first two modes of the wind stress curl show oscillations on an annual basis; the extremes agree well with those in the corresponding sea level modes. The extreme positive and negative coefficients of mode 1 are in December and August, respectively, corresponding to the reversal of winter and summer monsoons. A positive coefficient contributes positive curls to the southern basin and negative curls in the northwest corner. The mode 2 coefficient has a positive peak in either fall or early winter, producing positive curls over the northern basin. In the deep basin, the mode 2 contribution is generally of the same sign as that from mode 1 in winter and of the opposite sign in summer. Mode 2 contributes to the asymmetry in the wind stress curl forcing in these two seasons.

The timing of the mode 2 peak varies from year to year: August-October in 1992 and 1994 and December in 1993. In 1993, persistence of a positive mode 2 coefficient through December enhances the curl in the winter monsoon (figure 13). The early sign changes in mode 2 coefficients in late 1992 and 1994 quickly diminish the curl in the deep basin. In August, mode 1 contributes negative curls to the southern basin, and mode 2 provides positive curls in the northern basin. This is the case in August 1994. The two form a dipole off Vietnam, as shown in figure 14. The coefficient of mode 2 is small or negative in July 1993; the dipole structure off Vietnam is missing. The mode 2 contribution strengthens the wind stress curl forcing in the central basin in late 1993 and strengthens the dipole in the wind stress curl field in summer 1994. 


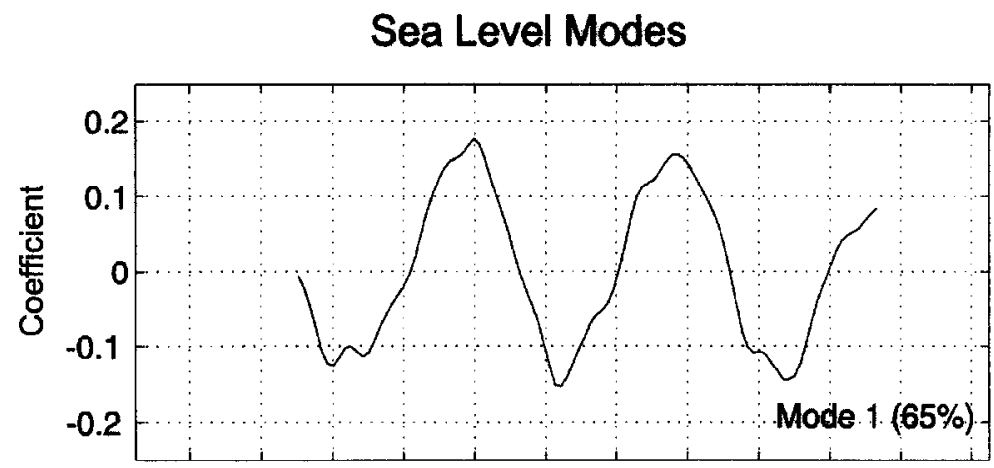

Figure 10. Temporal variations of sea level modes 1 and 2. Time marks are at the first day of the month indicated.

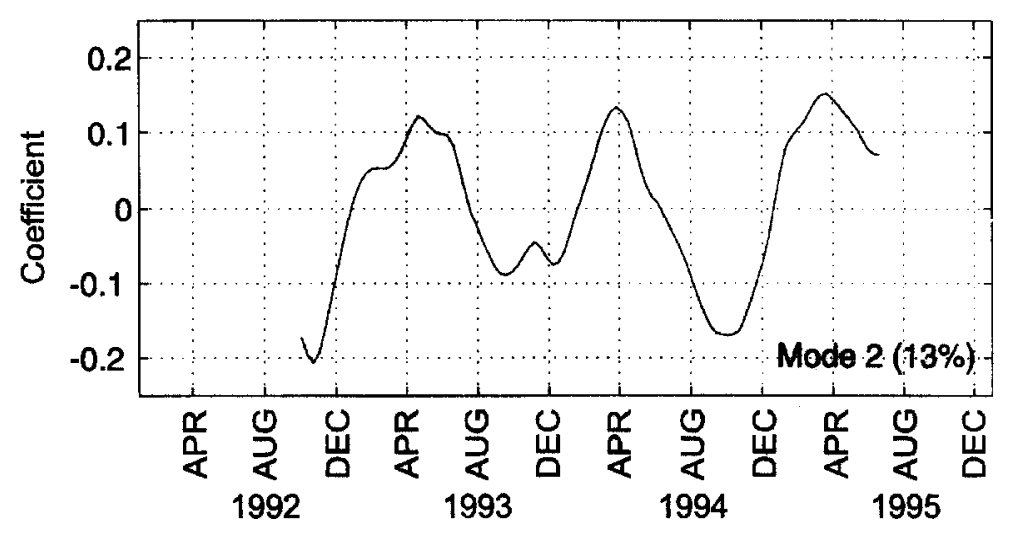

Wind Stress Curl Modes

Figure 11. Temporal variations of wind stress curl modes 1 and 2 . Time marks are at the first day of the month indicated. The monthly winds are plotted at the $15^{\text {th }}$ day of each month.
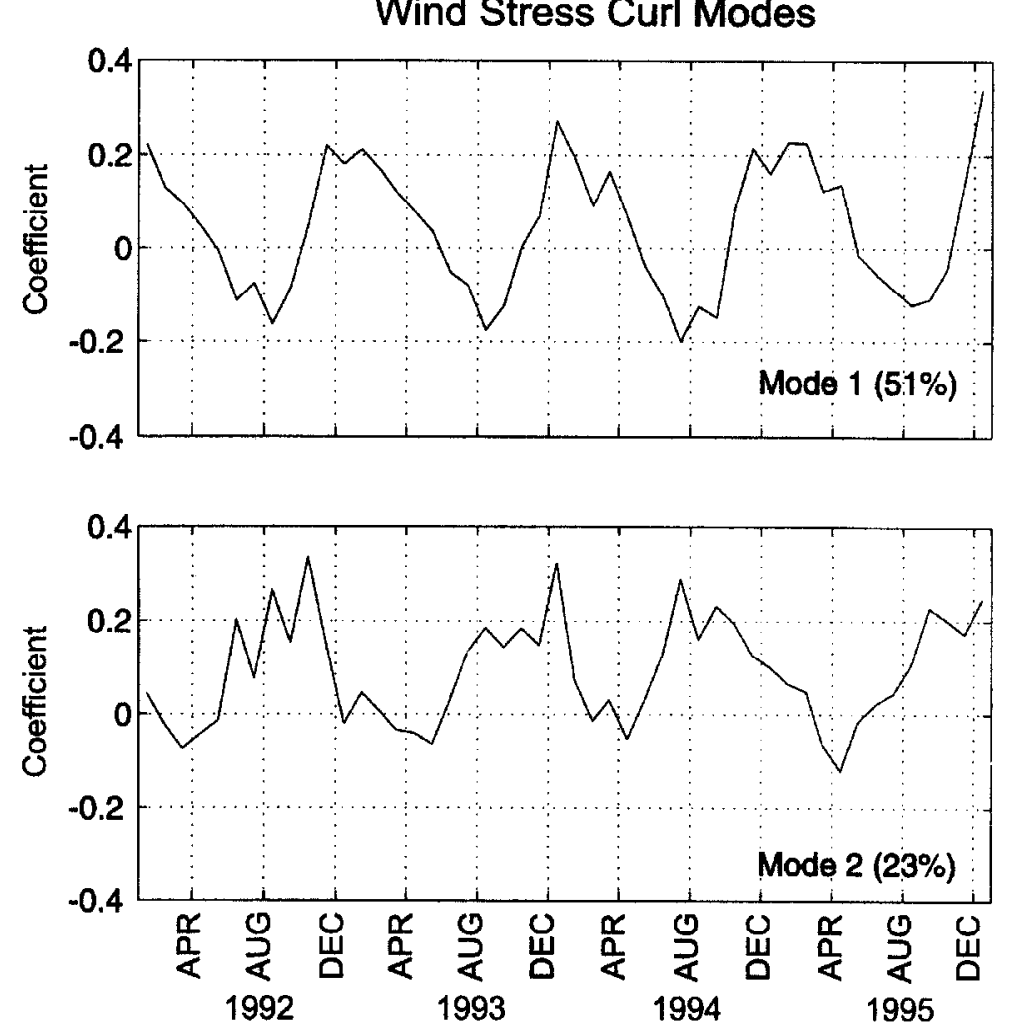

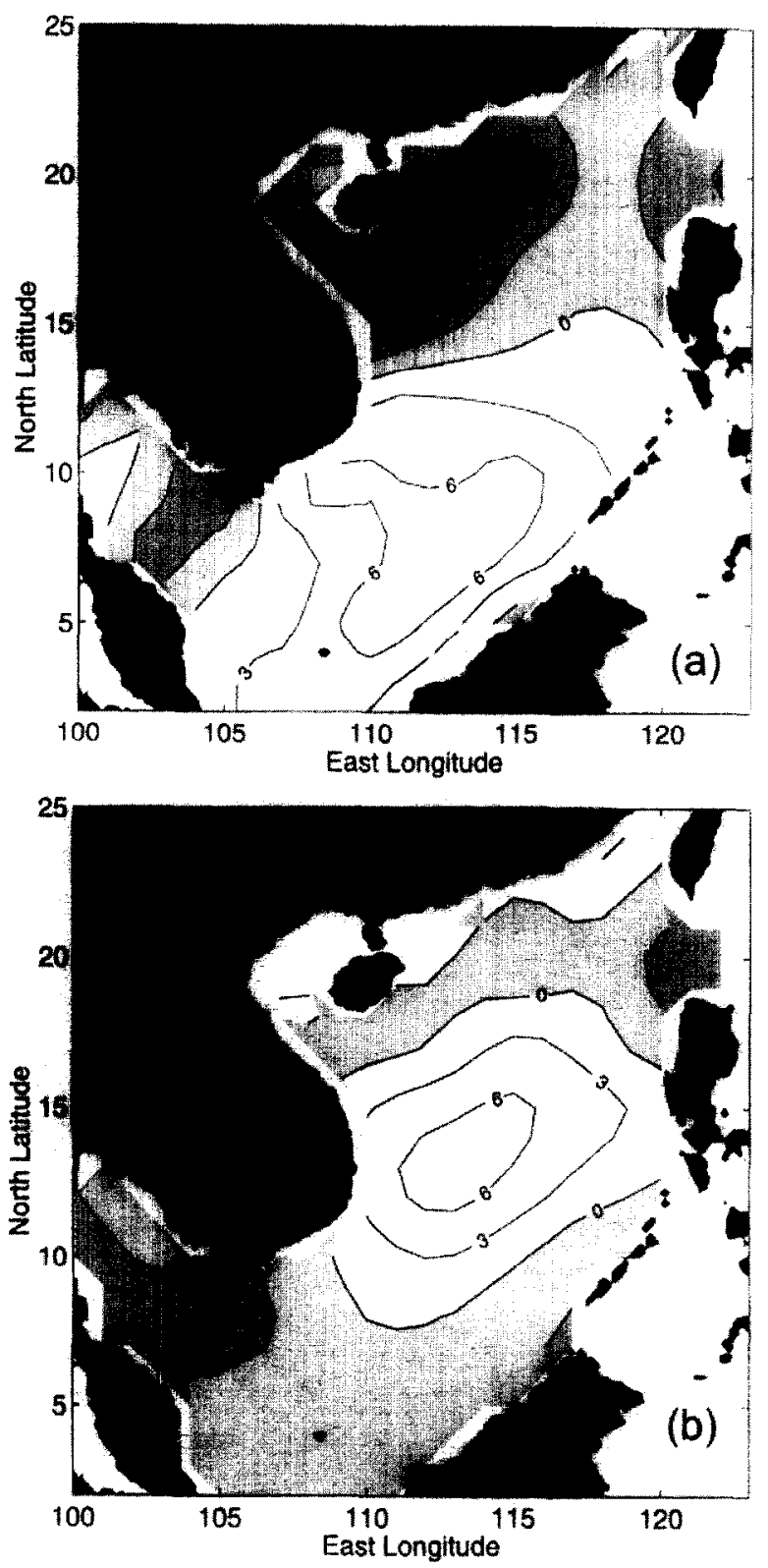

Figure 12. Spatial structure of the first two modes of the wind stress curl. Contours intervals are $3 \times 10^{-7} \mathrm{~N} \mathrm{~m}^{-3}$, and negative contours are shaded.

\section{DISCUSSION}

An important question concerning the dynamics of circulation in the South China Sea is whether the circulation is driven by wind stress itself or the curl of wind stress. Conceptually, a steady wind acting on a two-layer, $f$ plane ocean would set up sea level on the downwind side
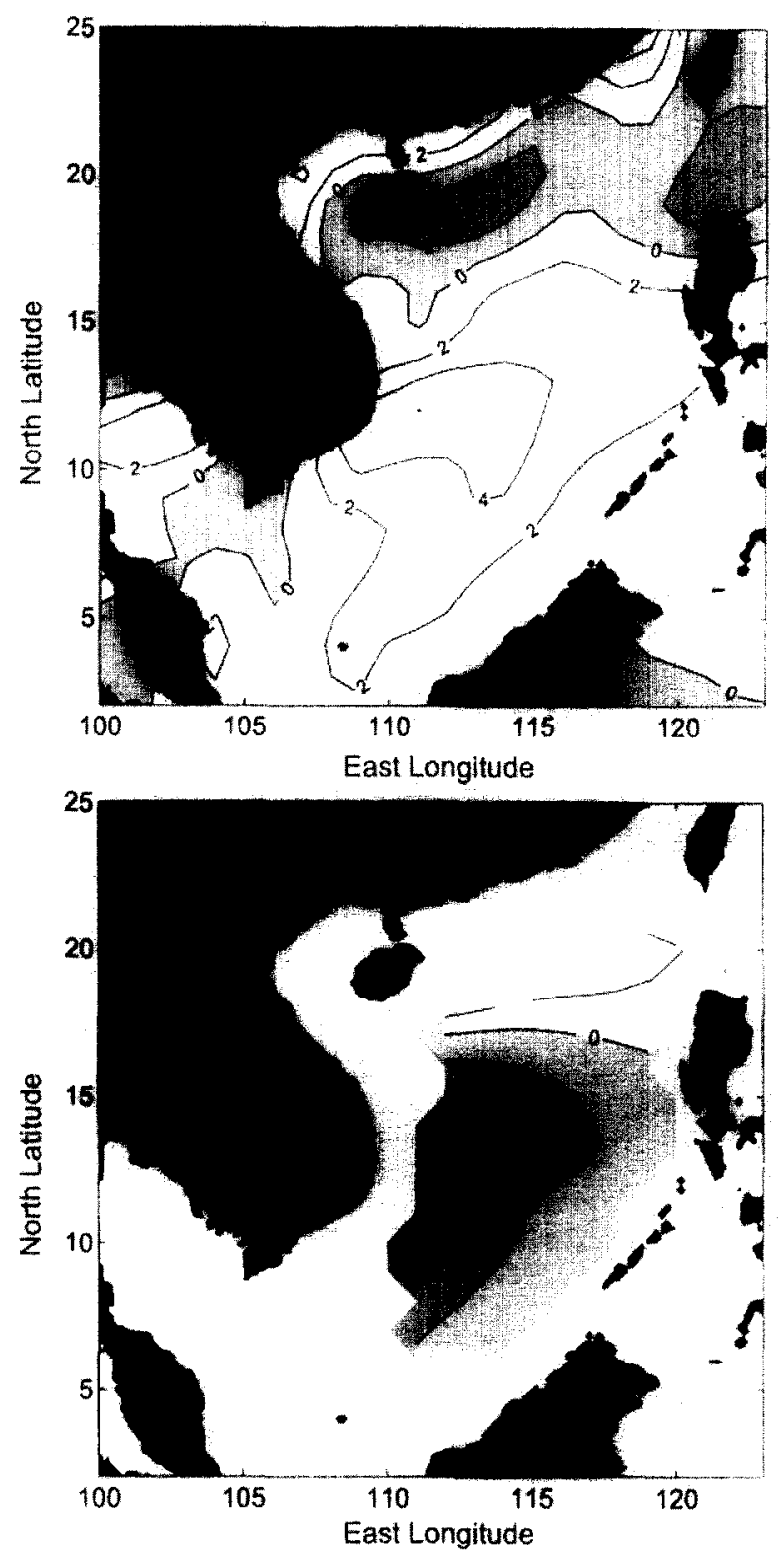

Figure 13. Monthly wind stress curl (upper panel) and the meridional geostrophic transport integrated from the eastern boundary in December 1993. Contour intervals are $2 \times 10^{-7} \mathrm{~N} \mathrm{~m}^{-3}$ and $4 \times 10^{6}$ $\mathrm{m}^{3} \mathrm{~s}^{-1}$ in the upper and lower panels, respectively. Negative values are shaded.

of the basin within one baroclinic Rossby radius of deformation from the side wall [5]. An $f$-plane model could explain the setup in sea level by the wind stress in the southwest corner of the South China Sea and along the coast of Vietnam in winter. However, a gyre intensifying along the western boundary requires wind stress curl 

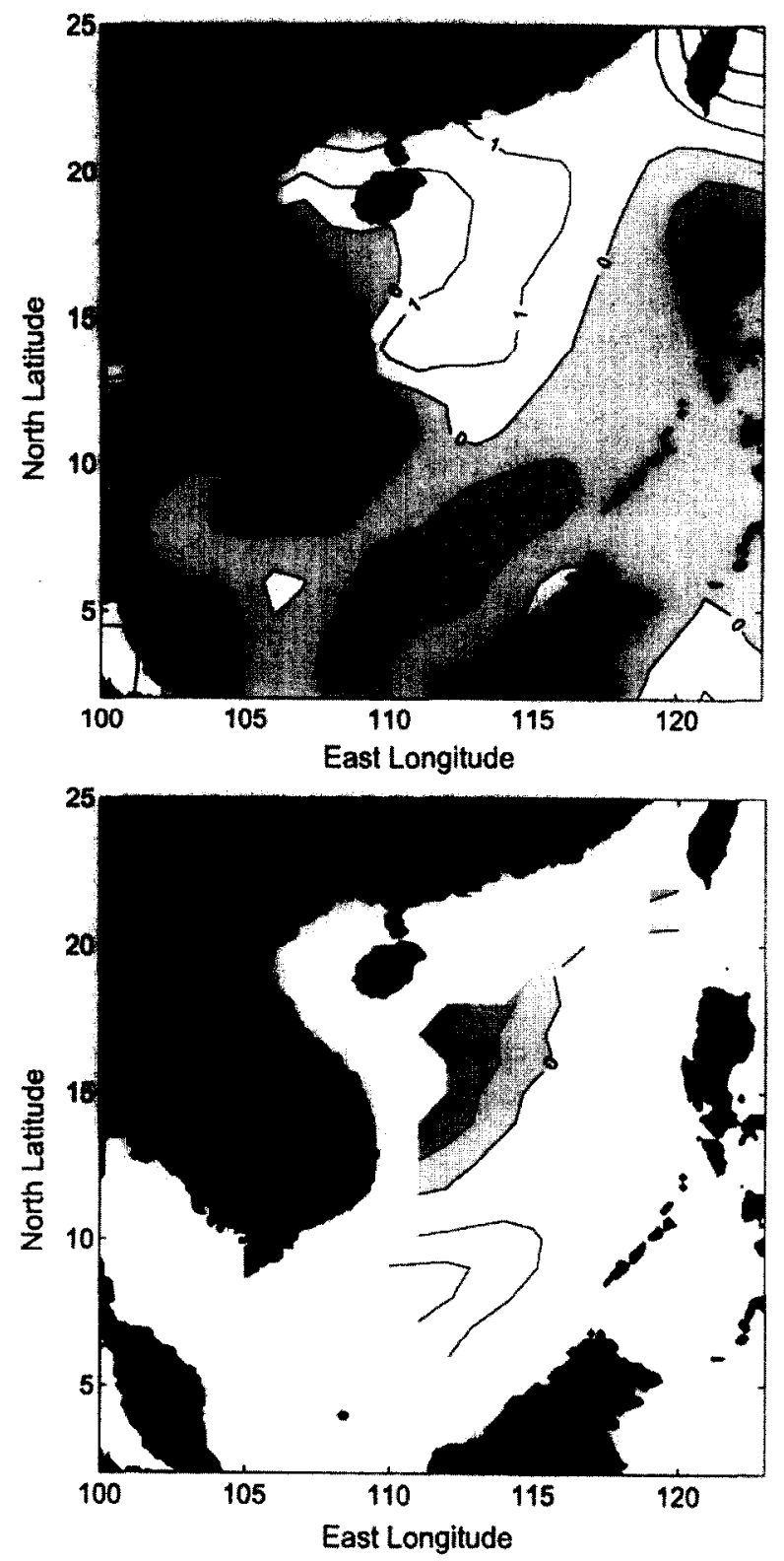

Figure 14. As figure 13 but in August 1994 with contour intervals $1 \times 10^{-7} \mathrm{~N} \mathrm{~m}^{-3}$ and $1 \times 10^{6} \mathrm{~m}^{3} \mathrm{~s}^{-1}$ in the upper and lower panels, respectively.

forcing on a $\beta$-plane according to Stommel [17]. The numerical experiments of Chao et al. [4] affirm the importance of $\beta$ in producing the winter circulation gyre. Without the $\beta$-effect, a weak cyclonic gyre appears in the southern basin where the wind stress curl is positive locally. Therefore, both the $\beta$-effect and the wind stress curl are essential to produce the basin-wide circulation in winter. In summer, separation of the coastal jet off Vietnam follows essentially the line of zero wind stress curl, fitting even better the classical gyre theory of Stommel.

The two modes of wind stress curl distribution in figure 12 are similar to those of sea level in figure 9 . The mode 1 wind stress curl is of the same sign south of $15^{\circ}$ $\mathrm{N}$. Thus, the gyre produced by the mode 1 wind stress curl would cover the entire deep basin south of that latitude, stronger off Sunda Shelf. The mode 1 sea level is of the same sign over the entire deep basin with maxima off the Sunda Shelf and Luzon (figure 9). The southern maximum in mode 1 sea level corresponds well to a curldriven gyre. The second sea level maximum located west of the Luzon Strait can not be explained by the wind stress curl. Strong curls of the opposite sign in the northern basin are mostly in shallow waters near the continental margin south of China. It is expected that the wind stress would dominate the curl there. In addition, inflow of warm Pacific water through the Luzon Strait in late fall and early winter [13] may contribute to the extreme sea level off Luzon. Thus, the mode 1 wind stress curl is the main contributor to the mode 1 sea level variation in the southern basin. The wind stress curl field associated with mode 2 shows a maximum off central Vietnam (figure 12). This maximum corresponds well to the large mode 2 amplitude in sea level (figure 9). Westward intensification on a $\beta$-plane could explain why the maximum sea level is near the coast of Vietnam. The mode 2 wind stress curl, which forces a gyre in the central basin, contributes to the sea level variation off central Vietnam.

Following the common practice in the study of ocean circulation on a $\beta$-plane [6], the sea level field from the satellite altimeter is compared to $\Psi$, the meridional geostrophic transport integrated along latitude circles from the eastern boundary. The geostrophic transport is obtained by subtracting the meridional Ekman transport from the Sverdrup transport. The latter is calculated from the monthly wind stress curl, while the Ekman transport is found from the wind stress. In the calculation, only data in areas where bottom depth is greater than $1000 \mathrm{~m}$ are included. The comparison is based on the assumption that sea level along the eastern boundary is zero. This is not the case at latitudes of the Luzon Strait, where inflow and outflow exist. Thus, interpretation for these latitudes must be cautious. Wind stress curls in December 1993 and August 1994 are used. As demonstrated in the previous section, winds in these two months are strong and are representative of normal climatology in winter and summer, respectively. 
Figure 13 shows the wind stress curl and the corresponding geostrophic transport integrated along latitude lines in December 1993. It is negative south of $17^{\circ} \mathrm{N}$, latilude of zero wind stress curl, consistent with a negative sea level anomaly over the deep basin in figure $7 \mathrm{f}$. Assuming the geostrophic velocity is uniformly distributed in the upper $250 \mathrm{~m}$ of the water column, $\Psi=10^{7} \mathrm{~m}^{3} \mathrm{~s}^{-1}$ would give a sea level rise of $10 \mathrm{~cm}$ at $10^{\circ} \mathrm{N}$, similar to that in figure $7 \mathrm{f}$. Note that considering inflow at the Luzon Strait in figure 13 would result in negative $\Psi$ north of $18^{\circ} \mathrm{N}$ both at the eastern boundary and in the interior to the west and would give a better comparison there. The wind stress curl and $\Psi$ in August 1994 are shown in figure 14. The dipole structure in $\Psi$ matches that in sea level in figure $7 \mathrm{~g}$ well.

Because of the small year-to-year variation of the model 1 wind stress curl (figure 11 ), the reversal in the direction of the Sunda gyre in winter and summer should be regular. Contributions to inter-annual variations are mainly from mode 2. During normal years, a strong positive mode 2 wind stress curl in the northern basin produces an expansive sea level depression in late fall and earlier winter. This sea level depression enhances the cyclonic northern gyre and strengthens the southward coastal jet off central Vietnam. As both are cyclonic, the northern gyre and the southern gyre off Sunda combine to form the climatological winter circulation over the entire basin. During years of weak winds, the mode 2 wind stress curl is either diminishing or negative after October, and the sea level depression in the central basin is reduced in size accordingly. Both the northern gyre and the southward coastal jet off Vietnam are weakened. During summer in normal years, wind stress curl contributions from the two modes form a dipole, producing a two-gyre circulation pattern with an eastward jet separating from the coast off central Vietnam. Without contribution of the wind stress curl from mode 2 , the northern gyre and the eastward jet diminish. The result obtained from the altimeter sea level and winds agrees with the earlier model prediction that weak circulation in the South China Sea during El Niño years is due to weakened monsoon winds [4].

\section{SUMMARY AND CONCLUSIONS}

The agreement between the wind and sea level fields and between the sea level fields from data and numerical simulation suggest that the wind stress curl is the main driving force of the circulation in the deep basin of the South China Sea except near the Luzon Strait. The sea-level height field obtained from satellite altimetry consists of two major modes of oscillations. The first mode corresponds to a symmetric reversal of the winter and summer circulation. The second mode, strongest off Vietnam, produces the asymmetry between the two gyres. In normal years, the wind stress curl in winter is strong and positive in the central basin. A cyclonic gyre is present over the entire basin. In summer of normal years, the wind stress curl is positive in the northern basin and negative in the southern basin; two regions of opposite wind stress curl produce a dipole circulation with an eastward jet following the line of zero curl. During warm events, the wind stress curl in the central basin is weak in winter, resulting in a weakened circulation gyre. In summer, the weak negative curl in the northern basin prevents the formation of a dipole structure in the wind stress curl field. The northern gyre is not well defined, and the eastward jet is either weak or missing. The results are consistent with earlier descriptions of the climatological South China Sea circulation and its variation during El Niño.

\section{Acknowledgements}

The authors would like to thank the two reviewers for their detailed and constructive suggestions. This research was supported by the U.S. National Science Foundation under grants OCE95-02984 (PTS) and OCE95-04959 (SYC). Part of the research described in the paper was carried out by the Jet Propulsion Laboratory, California Institute of Technology, under contract with National Aeronautics and Space Administration. Support from the Topex/Poseidon Project funded under the NASA Topex/ Poseidon Announcement of Opportunity is acknowledged (LLF).

\section{REFERENCES}

[1] Callahan P.S., TOPEX/POSEIDON GDR User's Handbook, JPL D-8944, Jet Propulsion Laboratory, Pasadena, CA (1994) $81 \mathrm{p}$.
[2] Chao S.-Y., Shaw P.-T., Wang J., Wind relaxation as a possible cause of the South China Sea Warm Current, J. Oceanogr. 51 (I995) 111-132. 
[3] Chao S.-Y., Shaw P.-T., Wu S., Deep water ventilation in the South China Sea. Deep-Sea Res. I 43 (1996) 445-466.

[4] Chao S.-Y., Shaw P.-T., Wu S., El Niño modulation of the South China Sea circulation, Prog. Oceanogr. 38 (1996) $51-$ 93.

[5] Csanady G.T., Circulation in the Coastal Ocean, D. Reidal, Boston, $1982,279 \mathrm{p}$

[6] Gill A.E., Atmosphere-Ocean Dynamics, Academic, New York, 1982, $662 \mathrm{p}$.

[7] Goddard L., Graham N.E., El Niño in the 1990s, J. Geophys. Res. 102 (1997) 10423-10436.

[8] He H., Tidal characteristics along the south China coast, Trop. Oceanol. 6 (1987) 37-45 (in Chinese with English abstract).

[9] Kalnay E., Kanamitsu M., Kistler R., Colins W., Deaven D., Gandin L., Iredell M., Saha S., White G., Woollen J., Zhu Y., Chelliah M., Ebisuzaki W., Higgins W., Janowiak J., Mo K.C., Ropelewski C., Wang J., Leetmaa A., Reynolds R., Jenne R., Joseph D., The NCEP/NCAR 40-year Reanalysis Project, Bull. Amer. Meteor. Soc. 77 (1996) 437-471.

[10] Ma X.C., Shum C.K., Eanes R.J., Tapley B.D., Determination of ocean tides from the first year of Topex/Poseidon altimeter measurements, J. Geophys. Res. 99 (1994) 24,809-24,820.

[11] Mazzega P., Bergé M., Ocean tides in the Asian semienclosed seas from Topex/Poseidon, J. Geophys. Res. 99 (1994) 24,867-24,881

[12] Preisendorfer R.W., Principal component analysis in meteorology and oceanography, Elsevier, New York, 1988, 425 p.
[13] Shaw P.-T., The seasonal variation of the intrusion of the Philippine Sea water into the South China Sea, J. Geophys. Res. 96 (1991) 821-827.

[14] Shaw P.-T., Chao S.-Y., Surface circulation in the South China Sea, Deep-Sea Res. I 41 (1994) 1663-1683.

[15] Shaw P.-T., Chao S.-Y., Liu K.-K., Pai S.-C., Liu C.-T., Winter upwelling off Luzon in the northeastern South China Sea, J. Geophys. Res. 101 (1996) 16,435-16,448.

[16] Schlax M.G., Chelton D.B., Correction to "Aliased tidal errors in Topex/Poseidon sea surface height data". J. Geophys. Res. 101 (1996) 18,451.

[17] Stommel H.M., The westward intensification of wind-driven ocean currents, Trans. Amer. Geophys. Union 29 (1948) 202206.

[18] Trenberth K.E., Hoar T.J., The 1990-1995 El Niño-Southern Oscillation event: longest on record, Geophys. Res. Letters, 23 (1996) 57-60.

[19] Wyrtki K., Physical Oceanography of the Southeast Asian Waters, NAGA Report Vol. 2, Scientific Results of Marine Investigations of the South China Sea and the Gulf of Thailand, Scripps Institution of Oceanography, La Jolla, Calif. (1961) $195 \mathrm{p}$.

[20] Zhang Y., Sperber K.R., Boyle J.S., Climatology and interannual variation of the East Asian winter monsoon: Results from the 1979-95 NCEP/NCAR reanalysis, Mon. Weather Rev. 125 (1997) 2605-2619. 